\title{
Would Team Reputation Effect on Spectator Supportive Behavior?
}

\author{
Mahdi Latifi Fard ${ }^{1}$, Hossein Akbari Yazdi ${ }^{2}$, Marjan Saffari ${ }^{3}$ \\ 1. Mahdi Latifi Fard, (M.A) Kharazmi University, Tehran, Iran \\ 2. Hossein Akbari Yazdi, (Ph.D) Kharazmi University, Tehran, Iran \\ 3. Marjan Saffari, (Ph.D) Tarbiat Modares University, Tehran, Iran
}

\section{ARTICLE INFO \\ Received January 2018 \\ Accepted July 2018}

\section{KEYWORDS:}

Communication

Management Quality

Reptrak Pulse

Reputation

\section{CITE:}

Latifi Fard, Akbari Yazdi, Marjan Saffari, Would Team Reputation Effect on Spectator Supportive Behavior? Research in sport management \& motor behavior, 2020: $9(18): 71-91$

\section{ABSTRACT}

Although reputation construct enters early in sport but; not only supportive behavior isn't new question, but also always have been noticed by sport teams. The present research is in search of be clarify that is sport that is prominent setting of emotion and feeling of spectator and fans, team reputation can appear spectator supportive behavior? In this research number of 580 persons as sample from spectator population's fc. Esteghlal and Persepolis F.C. selected. Questionnaires because reputation emotional component (reputation perception construct) Were distributed as online that game day's emotion didn't impact on spectator answer. Jang et al. (2015) team reputation questionnaire consist of 6 subscales and 19 items, Ponzi et al. 2011 supportive behavior and reputation perception everyone had 4 items that adjusted in 5-points Likert scale. Questionnaire content validity have been evaluated by 7 professors in sport management. Alpha Cronbach's coefficient has been measured for reliability. Confirmatory factor analysis (CFA) also used for construct validity. indeed, shown that team reputation predicted $\% 42$ changes of supportive behavior without reputation perception while with Presence this predicted \%24. In conclusion reputation perception as emotional construct have more impact on supportive behavior than Functional and cognitive component. 


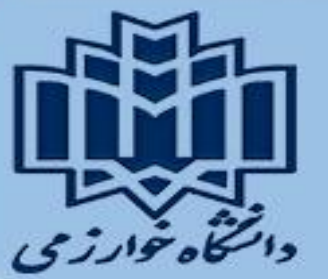

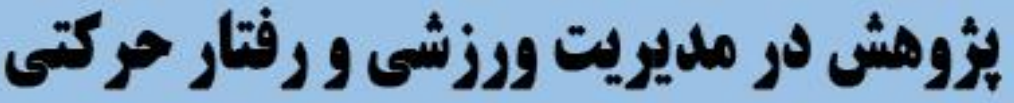

\section{آيا خوشفامى تيم، محركى بر رفتار هاى حمايتى تماشاكران خواهد بود؟

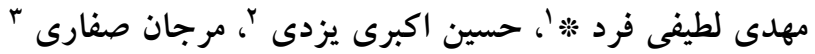

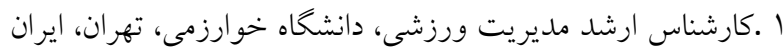

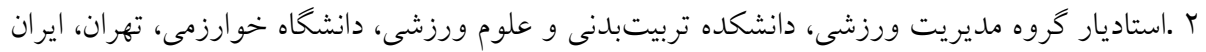

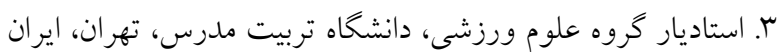

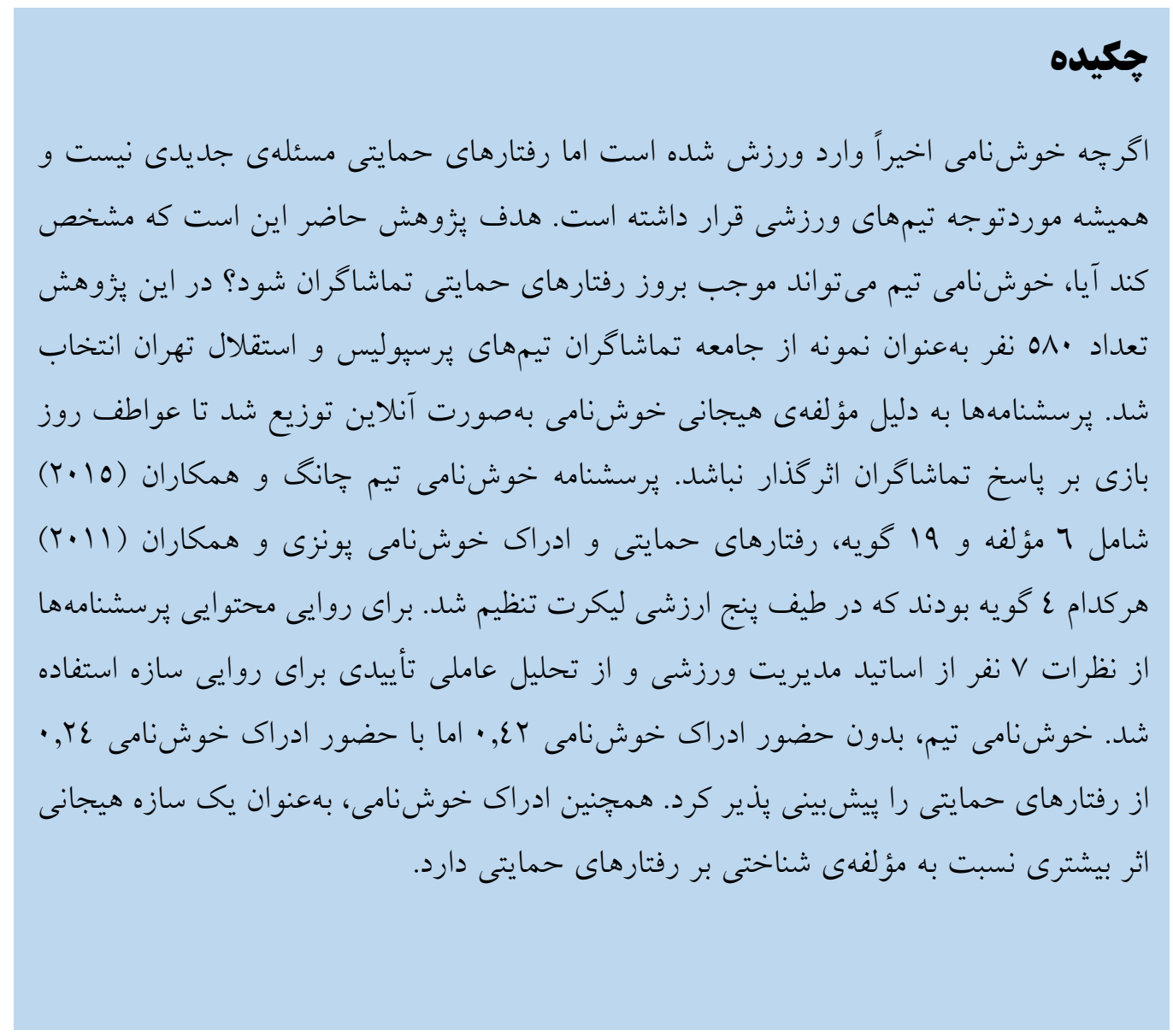

اطاعات مقاله:

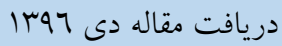

يذيرش مقاله تير MV

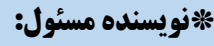

mahdi_latifi2001@yahoo.com

وازههاى كليلاى:

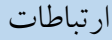

خوشنامى

كيفيت مديريت

نبض خوشنامى

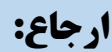

لطيفى فرد، اكبرى يزدى، صفارى. آيا خوشنامى تيم، محركى بر رفتارهاى

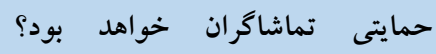
يزّوهش در مديريت ورزشى و رفتار

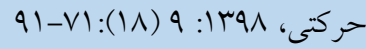

https://jrsm.khu.ac.ir/ 


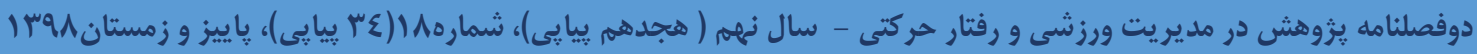

مقدمه

ذينفعان از ديدكاه خود، سازمان را در مركز يك شبكه از ارتباطات با ذينفعان مختلف مىبيند. اين افراد يا كروهها معمولاً سهامداران حقوقى، مصرف كنندكان، كاركنان، شركاى تجارى، دولتها، رسانه، جوامع محلى و زيست محيط است (1). در تعريف ذينفعان، بايد اشاره داشت كه ذينفع در يك سازمان هر گروه يا شخصى است كه مىتواند بر بهبود اهداف يك سازمان اثر بخذارد يا از آنها اثر بيذيرد (Y). شركتها و مشتريان بهعنوان مهم ترين ذينفع تمايل به مراجعه براى معامله با شركتهايى كه قابليت اطمينان را دركذشته ثابت كردهاند، دارند (r). اخر مشتريان شركتها و سازمانها برداشت منفى خود را از شركت يا محصولات آنها توسعه دهند، مطمئناً فروش و سود آنها سقوط خواهد كرد (ع). اهميت اين برداشتها و ادراكات صاحبنظران بازاريابى را بر آن داشته تا سازهاى براى سنجش اين مسئله طراحى كنند. خوشنامى بهعنوان سازهاى است كه در ايجاد برداشت مثبت يا منفى مشتريان نسبت به سازمان وارد حوزه بازاريابى شده است. نقش خوشنامى در جهان امروز تجارت بىشك عامل اصلى موفقيت يا شكست است (0) جر اكه شركتها نياز دارند تا تصوير مثبى از سازمان باهدف جذب مشتريان و سرمايه گذاران حفظ كنند (7). بايد افزود كه خوشنامى سازمان بهعنوان يك هـ

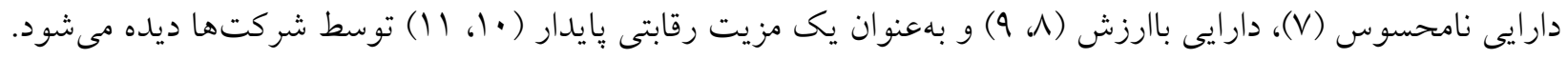
خوشنامى امروزه از نگاه صرفاً مالى گرايانه خارجشده است: ديد گاه اقتصاددان، ديدگاه استراتزيست، ديدگاه بازاريابى، ديدكاه سازمانى، ديد كاه جامعهشناختى و ديدكاه مالى (0)، رويكردهايى هستند كه براى تعريف منسجمى از خوشنامى در سازمان مورداستفاده قرار مى گيرد. درعين حال، با تكميل تعريف خوشنامى در طول سى سال كذشته، سعى بر اين شده تا براى هر كروه از سهامداران سازه خوشنامى خاصى طراحى شود. به همين سبب خوشنامى بر مبناى مشترى يك اندازه كيرى منحصربهفرد است كه خوشنامى سازمان را از ديدكاه مهمترين سهامدار يعنى مشتريان ارزيابى مىكند (IT). در يكى تيم ورزشى مهمترين مشتريان تماشاگران هستند. براى شناسايى خوشنامى تيم بر اساس تماشاگران شش بعد شناسايى شده: 1. عملكرد تيم r. تاريخجه تيم r. مسئوليتهاى اجتماعى تيم ع. تماشاكر گرايى 0. سلامت مالى (Y). بايد افزود كه در توجه به تماشاگران بهعنوان مشتريان، خوشنامى سازمان مطلوب (نامطلوب) اثرات حياتى مثبت (منفى) بر متغيرهاى بيامدى مربوط به مشتريان دارد- وفادارى، اعتماد و نيات باز حمايتى - و ازاينرو بايد

$$
\text { مورد تمركز شركتها (تيمها) باشد (1). }
$$

كسن' (ع)، بيان مى (1) برد كه در موقعيت يك تيم ورزشى عملكرد تيم درواقع معادل مفهوم كيفيت محصول شناخته مىشود. يك سازمان با خوشنامى خوب براى ارتباط عاطفى سازمان با مردم، آنها را از طريق خريد، سرمايه كذارى و

\section{Kesenne}

https://jrsm.khu.ac.ir/ 
كار جذب مى كند. بهعبارتديخر، سازمانها به دنبال اين هستند كه مشتريان با سازمان آنها ارتباط داشته باشند (01). در يك تيم ورزشى، اين عملكرد است كه تماشاكران را به خريد بليت بازى و ديخر محصولات مرتبط با تيم ترغيب مى كند. باين حال در يك مفهوم وسيعتر، خوشنامى از جمع تمام فعاليتهاى تاريخى سازمان ايجاد مىشود (YI) كاروآنا و

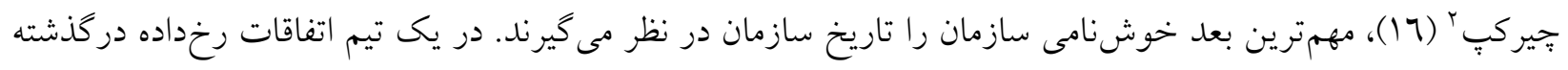
تيم مى تواند نقش مهمى در ايجاد تاريخجه ايفا كند؛ بنابراين، درك تماشاكران از خوشنامى تيمهاى ورزشى قادر است همجنين از سطح موفقيت آنها در كذشته (مانند موقعيتهاى بيروزى) ساخته شود (Y (I). شركتها بهعنوان بازيخرانى كه بايد براى سرمايه عمومى جامعه اقدام كنند و بنطور فزايندهاى بهعنوان افراد داراى شخصيتهاى مستقل رفتار كنند، ديده مىشوند. اخر جه شركتها بهتدريج ارزشهاى خود را به فعاليتهاى مسئوليت اجتماعى محسوس تفسير مى كنند، اما ارتباط ارزشها بين ذينفعان و شركت تضمين نمىشود، بلكه يك مكانيسمى از ارتباطات و بازخورد بايد با مخاطب و جامعه بهطوركلى ايجاد شود (IV). كزارش مسئوليتهاى اجتماعى شركت به افشاى طرحهاى شركت كه نشاندهنده ظرفيت نخرانى هاى اجتماعى و محيطى در عمليات و معاملات تجارى با ذينفعان است، اشاره دارد (1) (1). درحالى كه ظاهراً كرايش قوى بهطورمعمول براى معيارهاى خوشنامى سازمان در مورد عملكرد مالى سازمان موجود است، اما توسعه بدنه كار تلاش كرده است تا ارتباط بين مسئوليتهاى اجتماعى و خوشنامى سازمان را

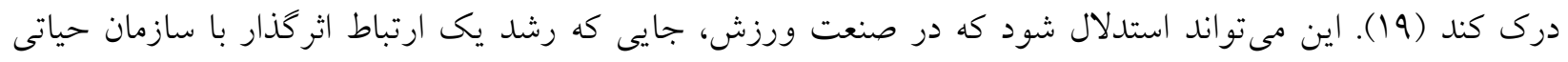
است، مسئوليتهاى اجتماعى قادر است ارزش ثانويه براى سازمان، برتر و بالاتر از جيزى كه در ديخر صنايع ديده مىشود، مهيا كند (·). مخصوصاً تيمهاى ورزشى قادر هستند، با حضور در فعاليتهاى مسئوليتهاى اجتماعى، ارتباط قوى ترى با طرفداران خود بسازند، درحالى كه به جامعه هم كمك مى كنند (Y) (I). توجه از سوى شركتها به مشتريان در حالى است كه مشتريان همجنين بهعنوان بخشى از بيان و ارتقا خود به ارتباط بيشتر خودشان با شركتهاى خوشنامتر تمايل دارند (• (1). پس شركتها بايد در مسير توجه به مشترى و مشترى گرايى از برنامه و استراتزىهاى مناسبى بيروى كنند؛ بنابراين، يك خوشنامى خوب به دليل اينكه مشتريان به سطوح بالاتر رقابت و كيفيت به شركت و درنهايت حمايت آن شركت كمك مى كنند، به آنها (مشتريان) مى يردازد (ب). البته، درحالى كه سازمان ورزشى مى تواند به طرفداران بهتنهايى براى توليد سود اتكا كند، سازمان ورزشى باهوش بايد تشخيص دهد كه همدى مشتريان طرفدار نيست و اينكه طرفدارى متعصبانه لزوماً يك بديده بلندمدت نيست (Y)؛؛ بنابراين، تيمهاى ورزشى نياز دارند تا تماشاكر گرايى را بهعنوان يك ارزش مركزى سازمان خودشان توسعه دهند (I (I).

\section{Caruana \& Chircop}

https://jrsm.khu.ac.ir/ 


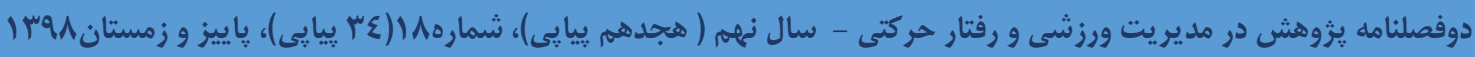

سهامداران مرتباً اطلاعات خود را در مورد اداره كردن شركت بهواسطه رسانه، مخاطبين يا خبر گزارىهاى دولتى توسعه مىدهند (YY). اداره سازمان ساختارها، فرايندها و اصول حقوقى درون سازمانها و محيط بير امون سازمانها كه تخصيص قدرت مى دهد و منابع را بين مشاركت كنندكان كنترل مى كند، توصيف مىشود (سY). اداره سازمان كه در اين يزوهش بانام كيفيت مديريت بهكاربرده مىشود، يكى از زيرمولفهاى خوشنامى تيم بهحساب مى آيد. در راستاى يك تيم ورزشى، مهارتهاى رهبرى مديران كليدى براى ساختن تيمهاى ورزشى بهعنوان بيشرو در ليخهاى خود بسيار مهم هستند. درنتيجه، يك سيستم مديريت اثربخش مىتواند به تيمهاى ورزشى براى ايجاد خوشنامى مثبت و قوى كمك كند (Y (I). آخرين بعد از خوشنامى تيم، بهسلامت مالى تيم اشاره دارد كه تعريفى از (استحكام و سودآورى مالى) است. تمام تلاشهايى كه در راستاى خوشنامى انجام مىشوند (درنتيجه به سودآورى بالاتر براى شركتهايى با (اخوشنامى خوب)" منجر مىشود) (ع (Y). همانكونه كه بيشتر بيان شد، خوشنامى يك دارايى نامحسوس است كه هيج ارزشى توسط قراردادهاى حسابدارى به آن اختصاص داده نشده است، اينيكى از مهمترين دارايىهاى ارزشمند است كه مستقيماً بر ارزش بازار يك شركت اثر مى گذارد (Y0). درنتيجه، تيمهاى ورزشى با توان مالى قوى مىتوانند ارتباطات بازاريابى خود را بيشتر توسعه دهند و عملكردهاى خود را درزمينه مربوط با به كار كرفتن مربيان توانمند و استخدام بازيكنان ستاره افزايش داده؛ بنابراين، اين قابل بيشبينى است كه سلامت (خوشفكرى) مالى تيمهاى ورزشى مىتواند بر خوشنامى

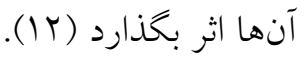

خوشنامى سازمان از نخاه گروههاى ذينفع در تمايل آنها بر ايجاد يا مضايقه كردن حمايت، اثر گذار خواهد بود (ع). علاوه بر اين، موفقيت در نظارت بر خوشنامى نه تنها در برابر نزول شركت ممانعت مى كند، بلكه قوياً ارزش سرمايه گذارى در سازمان را افزايش مىدهد (TY). بهعبارتديخر، اين استدلال شده است كه خوشنامى مثبت سازمان بيامدهاى مطلوب متعددى در بي خواهد داشت (V). اين در حالى است كه نيوبرى (YV)، رفتارهاى حمايتى را بزرگترين و مهمترين بيامد خوشنامى سازمانى مى داند. مسئله قابلتوجه اين است كه اخرجه مزاياى خوشنامى سازمان شناختهشده و تحسينبرانخيز است، سنجش آن مهجور مانده است (YN). ارتباط بين خوشنامى و رفتارهاى حمايتى نشانههايى از احتمال تداوم سودآورى است كه يك شركت را با جُشمانداز آتى قوى براى رشد نشان مىدهد (YN). خوشنامى مثبت براى شركتها با توجه به مزاياى عملكردى اين سازه، از طريق مكانيسمهاى كاهش هزينها و افزايش سرمايه، عملكردى آتى سازمان را

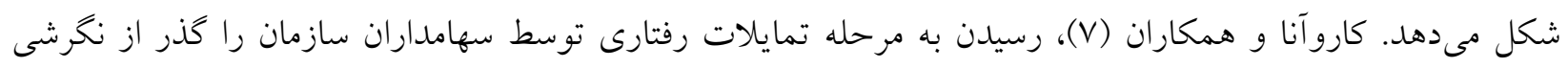
مى دانند كه اين گروهها نسبت به خوشنامى سازمان دارند. با بررسى انواع نهادههاى اطلاعاتىاى كه بر برداشت سهامداران 


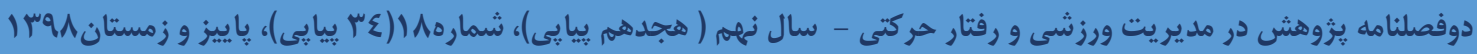

يكى شركت اثر مى كذارد، ما مى توانيم ابعادى را كه احتمالاً عكس العمل هاى هيجانى ذينفعان را از تحسين، دوست داشتن و اعتماد به شركت و خوشنامى آن بهتر بيشبينى كند، راهاندازى كنيم (YT). اين سيستم كه با نام نبض رييترك شناخته مىشود سازهاى است كه ارتباط هيجانى سهامداران و مشتريان را مىسنجد. يك نخرش تركيبى از سه مؤلفه اصلى است: اعتقادات رفتارى، احساسات و تمايلات رفتارى كه درنهايت به عمل منتج مىشود (V). براى رسيدن به تمايلات رفتارى و جيزى كه در عمل از مشتريان انتظار مىرود، برداشت آنها نقش واسطهاى ايفا مى كند؛ يعنى مرحله احساسات. افرادى كه شركتها را به عنوانى شركتهايى كه خوشنامى بهترى دارند درك مى كنند ممكن است بر اساس ادراك قوىترى از تناسب با اين شركتها، شركت را با رفتارهاى حمايتى دنبال كنند (TV).

طبق آخرين نظرسنجى برنامه نود، در سال זوسا تيم فوتبال يرسبوليس و استقلال بهعنوان برطرفدارترين تيمهاى ايران شناخته شدند. جهه عاملى در ايجاد اين طرفدارى اثر گذار بوده است؟ با توجه به حرفهاى شدن ليخ فوتبال ايران از سال

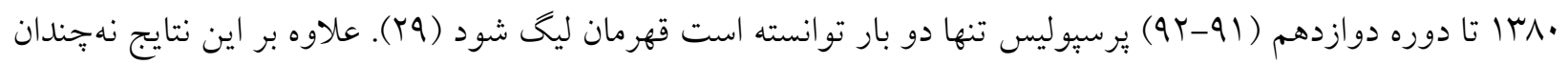
قابل توجه اين تيم در ليخ قهرمانان آسيا، حاكى از آن است كه شايد عامل ديخرى غير از نتايج و عملكرد تيم در طرفدارى اين تيم دخالت دارد. استقلال نيز كه سه بار توانسته است قهرمانى و سه بار نائب قهرمانى ليخ برتر را كسب كنند يكى از تيمهاى مطرح مىباشد. ميزان توجه تماشاگران به اين تيم نيز قابلتوجه است. بهطورى كه rVO هزار نقر از دنبال كنندكان صفحه رسمى اينستاكرام و سى هزار عضو كانال تلكرام اين تيم هستند. با توجه به اينكه استقلال بهطور كلى نتايج خوبى

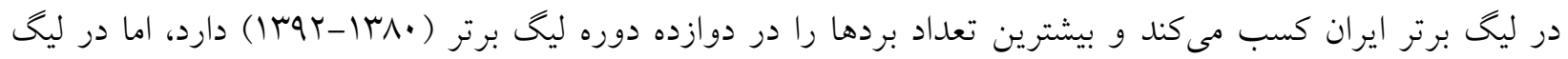
امسال با اقبال كمى از سوى تماشاكران خود مواجه شده است. با توجه به اين مسئله، در ورزش ايران سازهى خوشنامى بلهورت مجموعهاى از ديدكاههاى مختلف موردبررسى قرار نخرفته است. با بررسىهاى بهعملآمله مشخص شد در ورزش كمتر به خوشنامى توجه شده است. بخشنده و همكاران (·r)، به اين نتيجه رسيدند كه مسئوليتهاى اجتماعى بهنوان بيشبين خوشنامى قادر است تا VA درصد از تغييرات خوشنامى را بيشبينى كند.

اين يزوهش بهطور روشن به دنبال اين است كه بررسى كند آيا سازهى خوشنامى قابليت اثركذارى بر رفتارهاى حمايتى تماشاگر ان فوتبال را دارد يا خير؟ در مسير اثر گذارى خوشنامى تيم بر رفتارهاى حمايتى در ورزش نقش ادراك خوشنامى بررسى خواهد شد و مشخص مىشود كه نقش سازهى هيجانى خوشنامى بيشتر است يا نقش سازه شناختى آن. برهمين اساس شكل ا جارجيوب مفهومى و فرضيههاى يُزوهش را نشان مىدهد:

\footnotetext{
${ }^{4}$. Reptrak
}

https://jrsm.khu.ac.ir/ 


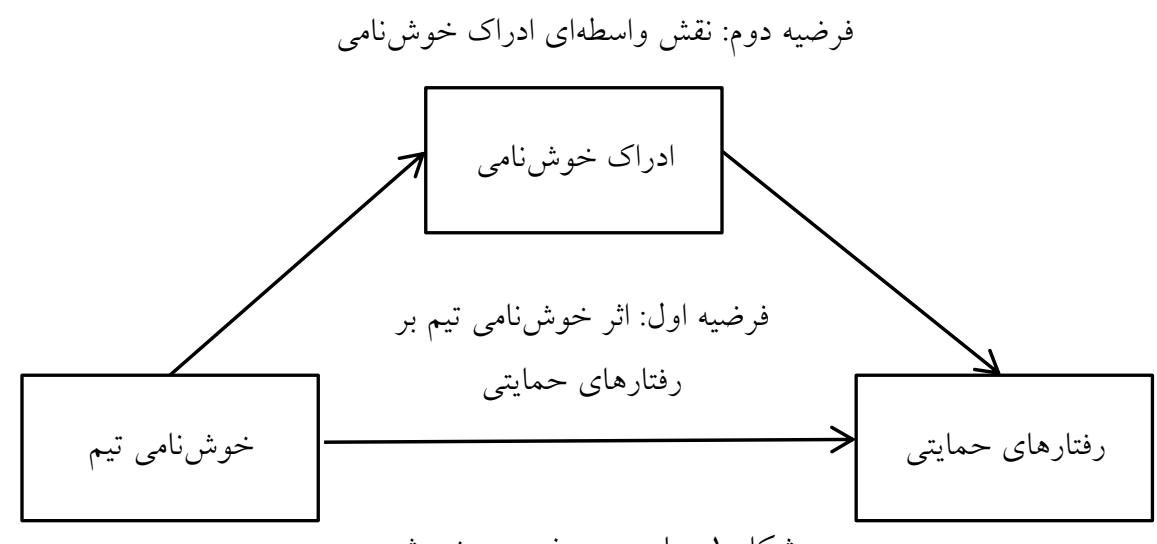

شكل 1. تحارجوب مفهومى يزوهش

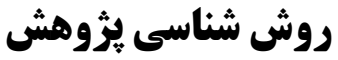

يزوهش حاضر از نوع كمى، همبستىى، توصيفى و كاربردى مى باشد. جامعه آمارى اين يزوهش را تمامى تماشاكران تيم

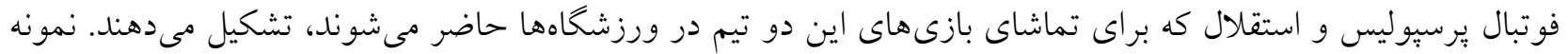

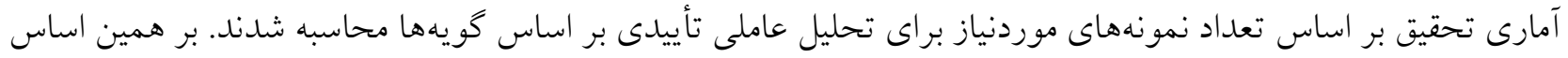

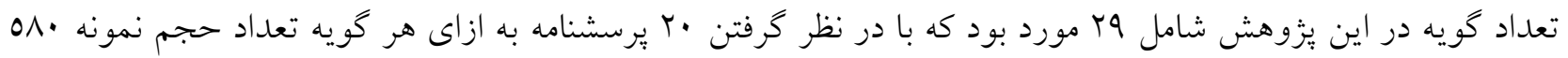

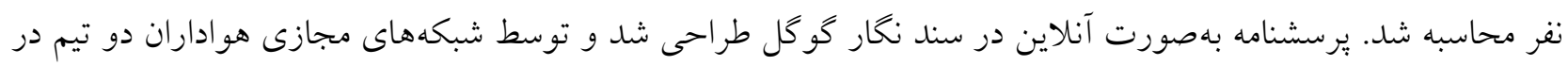

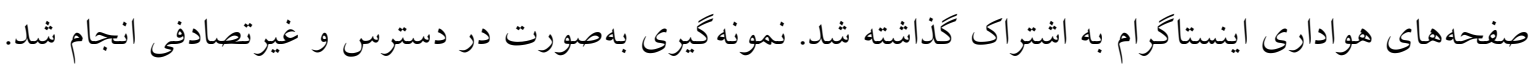

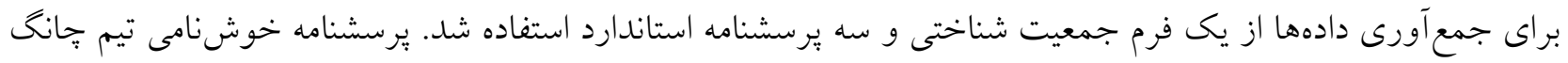

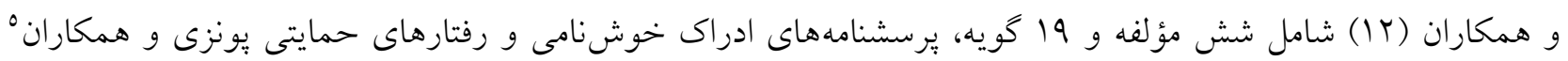

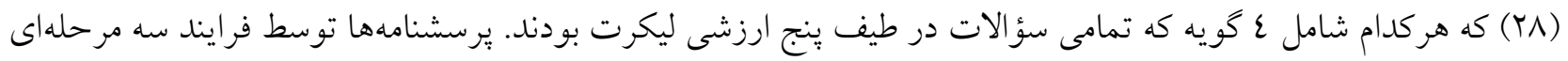

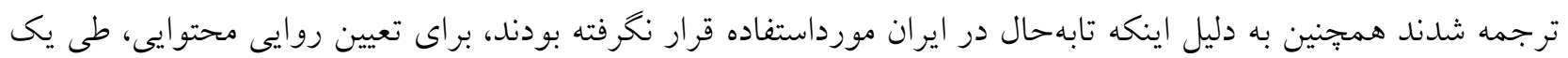
فرم اعتبار سنجى براى V نفر از اساتيد مديريت ورزشى صاحبنظر در حوزه كيفيت و بازاريابى ورزشى ارسال شد و

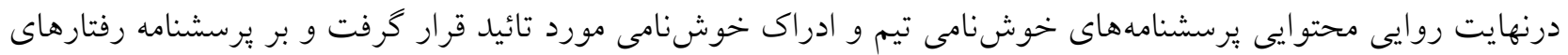

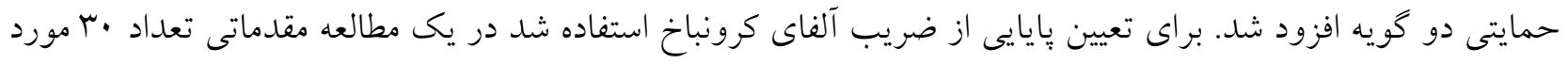

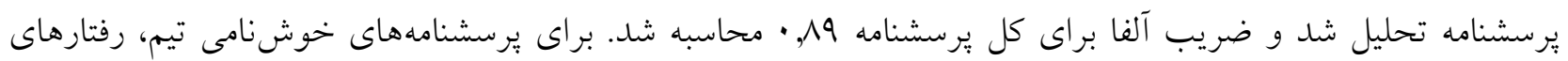

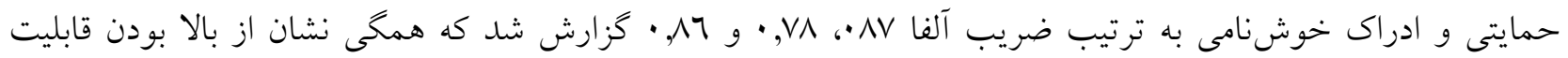

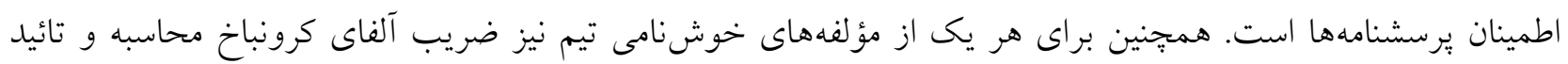

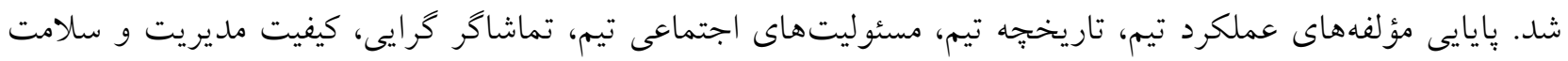

5 . Ponzi et al.

https://jrsm.khu.ac.ir/ 


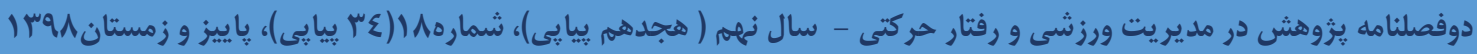

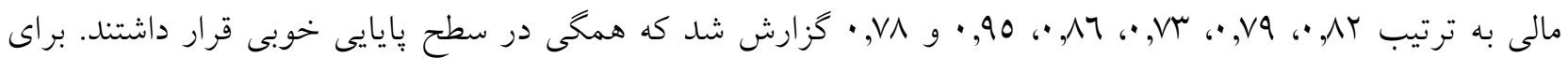

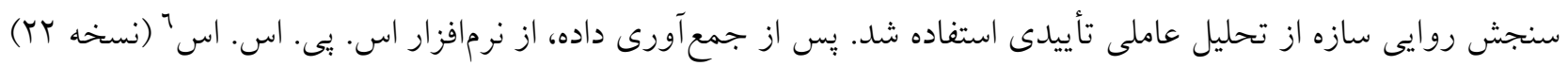

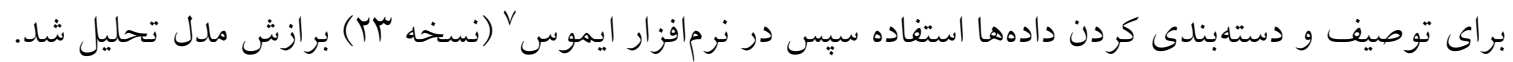

يافته ها

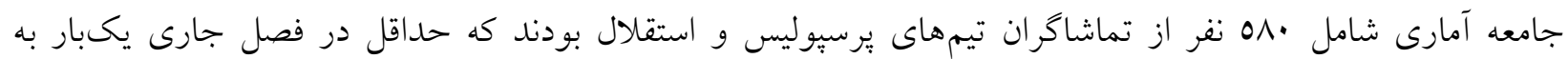

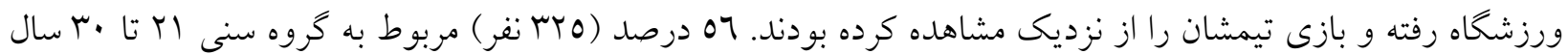
بودند كه بيشتريان مشاركت داشتند. در ميان حجم نمونه بيشترين سطح تحصيلات مربوط به دييهم و زير دييلم بودند كه بهتنهايى Y, بـ درصد از حجم نمونه را به خود اختصاص داده بودند. با توجه به اينكه اين تحقيق در مورد دو تيم برسبوليس

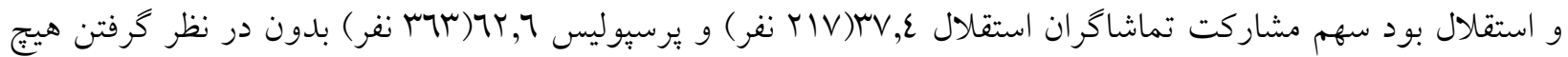

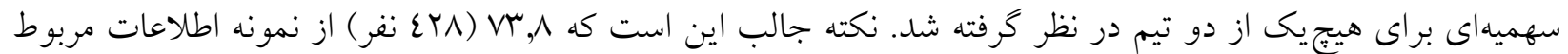
به تيم خود را از طريق شبكههاى اجتماعى كسب مى كنند و تنها يك نفر از طريق دوستان خود اطلاعات را دنبال مى كند.

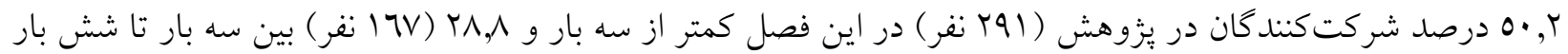

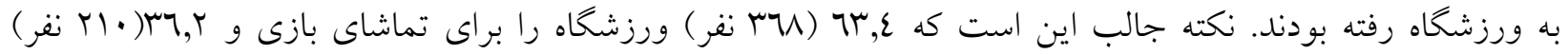

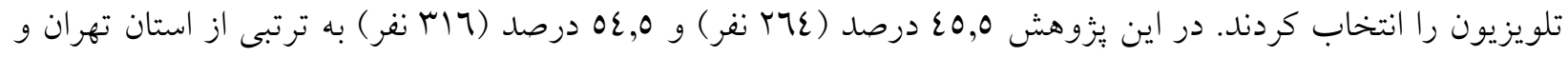
ساير استانها بودند. در ادامه بار عاملى هر يك از گويهها كه از تحليل عاملى مرتبه اول به دست آمده نمايش داده خواهد 
جدول 1. ضرايب مسير گويههاى خوشنامى تيم

\begin{tabular}{|c|c|c|}
\hline ضريب مسير & كويه & مولفه \\
\hline$\cdot, \mathrm{VO}$ & عملكرد بازيكنان تيم موردعلاقه من عالى است & \multirow{3}{*}{ 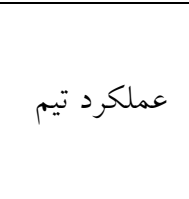 } \\
\hline$\cdot, 77$ & تيم موردعلاقه من بازيكنان باكيفيتى دارد. & \\
\hline$\cdot, \mathrm{V} 7$ & نتايج و عملكرد تيم موردعلاقه من مطلوب است. & \\
\hline$\cdot, \varepsilon r$ & تيم موردعلاقه من، در مقايسه با ديخر تيمهاى ليگ برتر، تيم قديمى و باسابقهاى است. & \multirow{3}{*}{ تاريخجه تيم } \\
\hline$\cdot, \mathrm{VT}$ & تيم موردعلاقه من، تاريخجه غنى و يربارى نسبت به ديخر تيمهاى ليخ برتر دارد. & \\
\hline$\cdot$, or & سابقه طولانى و داستانهاى تيم موردعلاقه من، امروز اين تيم را به يك تيم خاص & \\
\hline$\cdot$, , & بازيكنان تيم فوتبال موردعلاقه من به بهتر شدن سطح جامعه به كمك فعاليتهاى & \multirow{4}{*}{ مسئوليت هاى } \\
\hline$\cdot, \wedge 0$ & تيم محبوب من در بنيادهاى خيريه سرمايه كذارى مى كند. & \\
\hline$\cdot, \wedge 9$ & تيم موردعلاقه من بهطور منظم به خيريهها كمك مالى مى كند. & \\
\hline$\cdot, \mathrm{VT}$ & تيم موردعلاقه من براى شناسايى بازيكنان داوطلب به كار كردن در امور خيريه، & \\
\hline$\cdot, \wedge 7$ & تيم من، به هواداران خود توجه دارد. & \multirow{3}{*}{ تماشاگر گرايى } \\
\hline$\cdot, M$ & تيم من از حقوق طرفداران بهطورجدى دفاع مى كند. & \\
\hline$\cdot, \mathrm{Vq}$ & تيم محبوب من با هواداران مؤدبانه رفتار مى كند. & \\
\hline$\cdot, 94$ & مديريت باشگاه محبوب من جشمانداز روشنى براى آينده اين تيم دارند. & \multirow{3}{*}{ 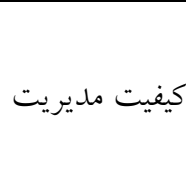 } \\
\hline$\cdot, 90$ & مديران باشكاه محبوب من افرادى برجسته هستند. & \\
\hline$\cdot, 9 \mathrm{~V}$ & مديريت باشخاه كارهاى بزرخى براى بيشرفت اين تيم انجام مىدهند. & \\
\hline$\cdot, \wedge \vee$ & عملكرد مالى تيم محبوب من خوب است. & \multirow{3}{*}{ 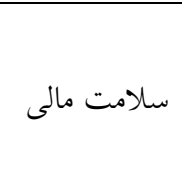 } \\
\hline$\cdot, \mathrm{Vr}$ & تيم فوتبال محبوب من وضعيت مطلوبى در سودآورى دارد. & \\
\hline$\cdot, \sqrt{ } \varepsilon$ & از لحاظ مالى تيم محبوب من نسبت به ديخر تيمهاى ليخ برتر عملكرد بهترى دارد. & \\
\hline
\end{tabular}

در كام بعدى ميانخين مؤلفههاى خوشنامى تيم، رفتارهاى حمايتى و ادراى خوشنامى موردبررسى قرار كرفت. جدول r ميانگين ياسخ شركت كنندگان را نشان مىدهد. مؤلفه تاريخجه تيم با توجه به نتايج تحليل عاملى تأييدى مرتبه دوم 


\begin{tabular}{|c|c|c|}
\hline ميانخين & متغير & \multirow{6}{*}{ خوشنامى } \\
\hline$\varepsilon, \pi$ & عملكرد تيم & \\
\hline$\varepsilon, \wedge \varepsilon$ & مسئوليتهاى اجتماعى & \\
\hline$\varepsilon, \Gamma)$ & تماشاكر گرايى & \\
\hline$r, o v$ & كيفيت مديريت & \\
\hline$r, \cdot 0$ & سلامت مالى & \\
\hline$\varepsilon, r V$ & \multicolumn{2}{|c|}{ رفتارهاى حمايتى } \\
\hline$\varepsilon, \wedge \varepsilon$ & \multicolumn{2}{|c|}{ ادراك خوشنامى } \\
\hline
\end{tabular}

همانطور كه اشاره شد جهت تائيد روايى سازه ابزار تحقيق از تحليل عاملى تأييدى استفاده شد. در جدول ب شاخصهاى مربوط به تحليل عاملى تأييدى برسشنامهها خوشنامى تيم، رفتارهاى حمايتى و ادراى خوشنامى ارائهشده است. جدول r. شاخصهاى برازش تحليل عاملى تأييدى مرتبه اول يرسشنامهها

\begin{tabular}{|c|c|c|c|c|c|}
\hline خوراز مقدار & رقدار برازش & خقدار برازش & نام لاتين شاخص & شاخص برازش & كروه شاخص \\
\hline $0, \cdot \cdot$ & $r 7,14$ & TrY,T & CMIN & كاى اسكوئر & \multirow{2}{*}{ شاخص هاى مطلق } \\
\hline r,o. & $r, q \cdot$ & r, ro & CMIN/DF & كاى اسكوئر نسبى & \\
\hline$\cdot, 9 \mathrm{~V}$ & $\cdot, 19$ & $\cdot, 9 \mathrm{~V}$ & IFI & شاخص برازش افزايش & \multirow{3}{*}{ شاخص هاى تطبيقى } \\
\hline$\cdot, 91$ & $\cdot, \wedge 1$ & $\cdot, 97$ & TLI & شاخص برازش توكر-لويس & \\
\hline$\cdot, 9 \mathrm{~V}$ & $\cdot, 19$ & $\cdot, 9 \mathrm{~V}$ & $\mathrm{CFI}$ & شاخص برازش تطبيقى & \\
\hline$\cdot$ & $\cdot, 01$ & $\cdot, 79$ & PNFI & شاخص برازش هنجار شده مقتصد & \multirow{2}{*}{ شاخص هاى مقتصد } \\
\hline$\cdot, \pi$ & $\cdot$, or & $\cdot, \mathrm{V}$ & PCFI & شاخص برازش تطبيقى مقتصد & \\
\hline$\cdot, 1 \varepsilon$ & 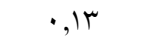 & $\cdot, \cdot 0$ & RMSEA & ريشه دوم ميانكين مربعات باقىمانده & شاخص بدى برازش \\
\hline
\end{tabular}

با توجه به اطلاعات منعكس شده در جدول ب شاخصهاى برازش براى خوشنامى تيم همخى از مقدار خوبى برخوردار

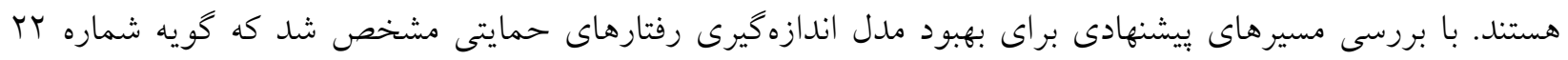

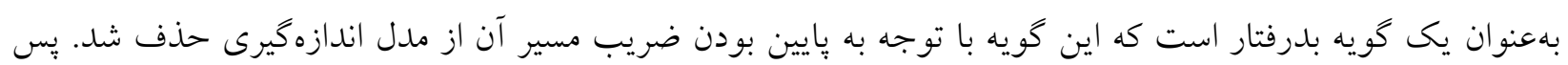
از حذف كويه شماره r شاخص هاى برازش همخى بهبود يافتند. يكى ديخر از شاخصهاى برازش شاخص RMR است 


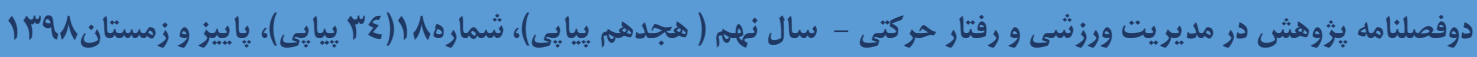

كه اين شاخص براى مقايسه دو مدل با دادهاى يكسان به كار گرفته مى شود. مقدار اين شاخص در مدل قبل از اصلاح (ع •, •) و كاهش آن در مدل بعد از اصلاح (r/, •) قابلقبول بودن مدل دوم را نشان مىدهد. از طرفى مقدار RMSEA به مقدار قابل قبولى كاهشيافته است و اين مدل با توجه به در نظر كرفتن تمامى شاخصهاى برازش، يعنى مدل اصلاح يافته قابل قبول است.

پِ از تحليل عاملى تأييدى مرتبه اول، محققين براى اطمينان بيشتر تنها خوشنامى تيم را كه مشتمل بر شش مؤلفه بود موردبررسى با استفاده از تحليل عاملى تأييدى مرتبه دوم قراردادند. در تحليل عاملى مرتبه دوم تمامى مسيرها از سطح

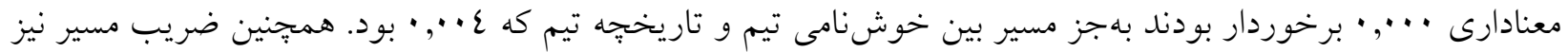
براى تاريخجه تيم و خوشنامى تيم 19, · بود؛ كه مقدار بسيار بايينى است. وجود مؤلفهاى زيربنايى كه به مقدار بسيار

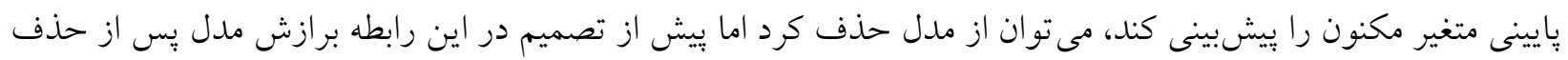

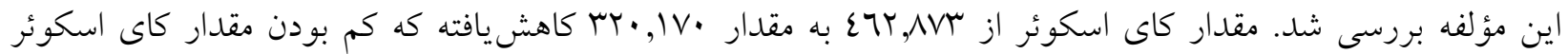
برازش خوب مدل را تائيد مى كند. شاخص برازش افزايشى، شاخص برازش توكر لويس و شاخص برازش تطبيقى به ترتيب به مقادير 97, ‘، ع 9, · و 97, • افزايش داشت. درنهايت محققين تصميم گرفتند با توجه به ضريب مسير پايين مؤلفهى تاريخجه تيم اين مؤلفه را از مدل حذف كنند. پِ از بررسى هاى مذكور، مدل كلى يُزوهش در نرمافزار amos اجرا شد تا برازش آن بررسى شود. تصوير شماره rا، مدل اثر خوشنامى تيم بر رفتارهاى حمايتى است كه در نرمافزار amos

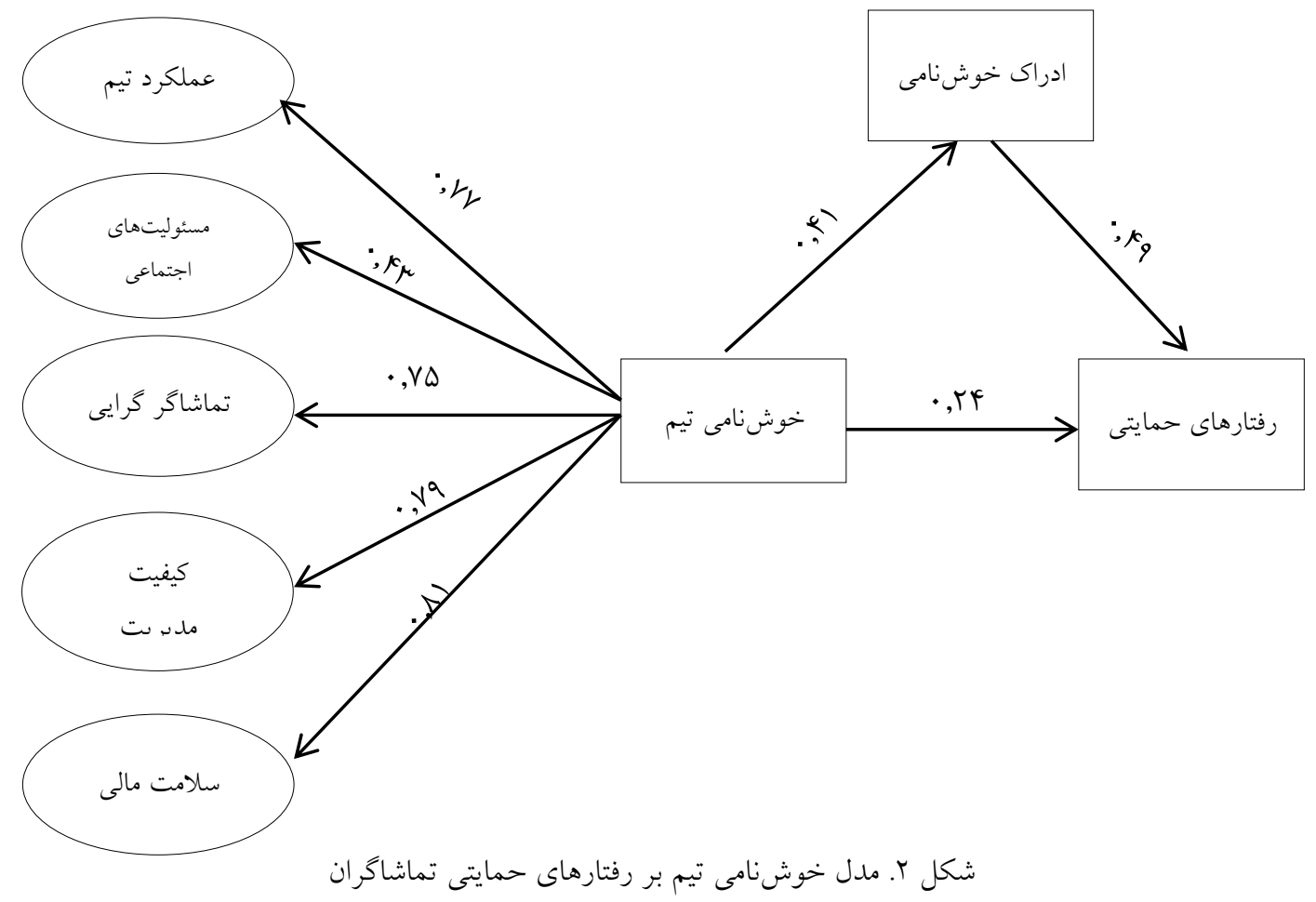

https://jrsm.khu.ac.ir/ 


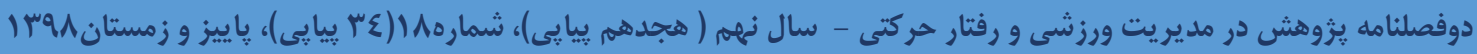

شاخصهاى برازش مدل خوشنامى تيم بر رفتارهاى حمايتى تماشاگران در جدول ع ارائهشده است. با توجه به شاخصهاى مندرج در جدول ع، شاخص كاى اسكوئر بهعنوان يك شاخص تطبيقى است كه با توجه به مقدار كاى اسكوئر مدل مستقل بررسى مى شود. هر جققدر اين شاخص از كاى اسكوئر مدل مستقل فاصله گرفته باشد نشان از برازش خوب مدل تدوينشده است كه با توجه به مقدار N1NV,079 براى مدل مستقل، اين شاخص در سطح بسيار خوبى قرار دارد. البته به دليل حساسيت بسيار بالاى كاى اسكوئر به درجات آزادى شاخص كاى اسكوئر نسبى نيز شاخص ديخرى است كه از اعتبار بيشترى برخوردار است. محدوده ا تا ه براى اين شاخص خوب در نظر كرفته مىشود.

\begin{tabular}{|c|c|c|c|}
\hline مقدار برازش & نام لاتين شاخص & شاخص برازش & كروه شاخص \\
\hline NIT,זTा & CMIN & كاى اسكوئر & \multirow{2}{*}{ شاخص هاى مطلق } \\
\hline$r, \cdot \sum r$ & CMIN/DF & كاى اسكوئر نسبى & \\
\hline$\cdot, q \pi$ & IFI & شاخص برازش افزايش & \multirow{3}{*}{ شاخص هاى تطبيقى } \\
\hline$\cdot, 94$ & TLI & شاخص برازش توكر -لويس & \\
\hline$\cdot, q \pi$ & $\mathrm{CFI}$ & شاخص برازش تطبيقى & \\
\hline$\cdot, \sqrt{ } \varepsilon$ & PNFI & شاخص برازش هنجار شده مقتصد & \multirow{2}{*}{ شاخصهاى مقتصد } \\
\hline$\cdot, \mathrm{V} 7$ & PCFI & شاخص برازش تطبيقى مقتصد & \\
\hline$\cdot, \cdot 7$ & RMSEA & ريشه دوم ميانكين مربعات باقىمانده & شاخص بدى برازش \\
\hline
\end{tabular}

همانطور كه ملاحظه مى شود شاخصهاى تطبيقى شامل شاخص برازش افزايشى، توكر - لويس و شاخص برازش تطبيقى هر سه مقدارى بالاى 9, · دارند كه بالاتر از اين مقدار نشان از برازش خوب اين شاخصها است. در رابطه با شاخصهاى مقتصد بايد اذعان داشت كه معمولاً مقدار 1, · را بهعنوان نقطه برش اين دسته شاخصها در نظر مى گيرند كه در اين مدل شاخصهاى مقتصد هر دو بالاى V, · هستند كه نشان از برازش بسيار خوب مدل است. درنهايت يكى از شاخصهاى بدى برازش يعنى ريشه دوم ميانخين مربعات باقىمانده موردبررسى قرار مى گيرد كه هرجقدر اين مقدار به ه •, • نزديكتر

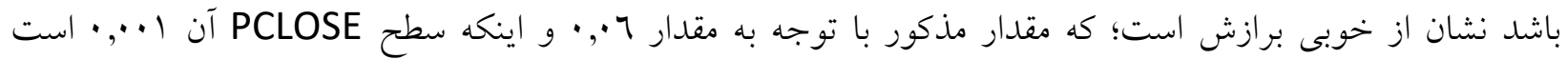
نشاندهنده برازش قابلقبول است.

بايد اضافه كرد كه در تعيين برازش كلى مدل بايد با توجه به جميع تمام شاخصهاى تصميمگيرى شود. هيجوقت يك معيار تعيين كننده نيكويى يا بدى برازش نخو اهد بود. اين حاكى از آن است كه اكرجه شاخص ريشه دوم ميانخين مربعات باقى مانده كمى از حد مطلوب و مجاز خود فاصله دارد اما با لحاظ كردن باقى شاخصها مىتوان جنين نتيجه كرفت كه مدل كلى يزوهش از برازش خوب برخوردار است. 


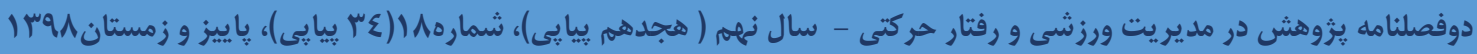

جدول ه ضرايب مسير را براى مدل يزوهش بين مؤلفههاى خوشنامى تيم، رفتارهاى حمايتى و ادراى خوشنامى را نشان مىدهد. اين بخش از يزوهش در يى باسخ به اين سؤال است كه كداميك از مؤلفهاى خوشنامى تيم اثر بيشترى بر هر يك از متغيرهاى رفتارهاى حمايتى و ادراك خوشنامى دارد. همجنين كدام مؤلفه اثر تعيينكنندگى بيشترى بر خوشنامى تيم دارد.

جدول 0. ضرايب مسير بين مؤلفهاى خوشنامى تيم و متغيرهاى بزوهش

\begin{tabular}{|c|c|c|c|}
\hline ادراك خوشنامى & رفتارهاى حمايتى & خوشنامى تيم & مؤلفهاى خوشنامى \\
\hline (سח, & $\cdot, \sum \varepsilon *$ & $\cdot, \mathrm{VV} *$ & عملكرد تيم \\
\hline$\cdot, \cdot Y-$ & $\cdot, 0 \varepsilon *$ & $\cdot,\{r *$ & مسئوليتهاى اجتماعى \\
\hline$\cdot,^{* *}$ & $\cdot, 20 *$ & $\cdot,>0 *$ & تماشاكر گرايى \\
\hline$\cdot, \cdot \varepsilon$ & $\cdot, 0 \varepsilon^{*}$ & $\cdot, \mathrm{vq} *$ & كيفيت مديريت \\
\hline$\cdot, \cdot 1$ & $\cdot, 71 *$ & $\cdot \wedge I^{*}$ & سلامت مالى \\
\hline
\end{tabular}

بحث و نتيجه تيرى

يزّوهش بيش رو به دنبال بررسى اثر سازهاى به نام خوشنامى تيم بر رفتارهاى حمايتى تماشاكران تيمهاى فوتبال برسبوليس و استقلال تهران بود. با توجه اطلاعات جمعيت شناختى بيش از بِنجاهدرصد شركت كنندكان كمتر از سه بار

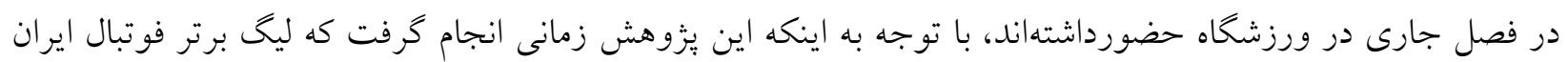
هفتهى بيست و جهارم را يشت سر كذاشته بود، از طرفى يكى از سؤالات مربوط به رفتارهاى حمايتى مربوط به اين است

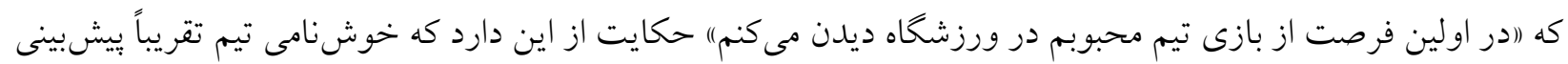
كننده رفتار حمايتى تماشاكران است.

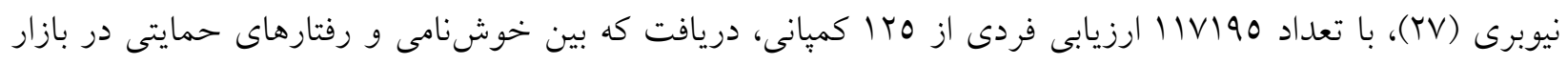
محصولات، سرمايه گذارى و نيروى كار ارتباط وجود دارد. نيوبرى رفتارهاى حمايتى را بزرگترين و مهمترين بيامد

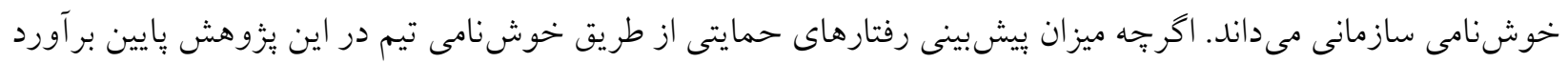
شده است اما جدول r نشان مىدهد ميانخين رفتارهاى حمايتى تماشاكران بالا است، اين درحالى كه است دو مؤلفهى خوشنامى تيم (كيفيت مديريت و سلامت مالى) كه بيشترين ضرايب مسير را در تخمين مقدار خوشنامى تيم دارد (ضريب مسير كيفيت مديريت= V9, · و سلامت مالى = (N, •) از مقدارى متوسط برخوردارند. با نخاهى به ضريب مسير بين مؤلفهاى خوشنامى تيم و رفتارهاى حمايتى مىتوان جنين برداشت كرد كه اخر جهه خوشنامى تيم بر وقوع رفتارهاى حمايتى اثر دارد اما در ورزش حتى اخر خوشنامى بهعنوان يك مؤلفهى شناختى در سطح بالايى برآورد نشود، كماكان رفتارهاى حمايتى را در بيى خواهد داشت. 


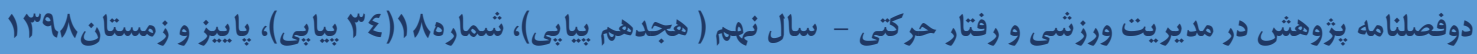

كليد اين مسئله كجاست؟ در بِاسخ به اين سؤال بايد بحث را به خواستگاه خوشنامى برد. خوشنامى يك شركت يك عنصر نامحسوس از استراتزى تجارى آن است. باوجوداين، شركت قادر است نيات رقابتى خود را نشان دهد (آم). تجارت! اين حلقهى مفقود اين ارتباط است. بهطور مثال رشد ارزش جايزه جام قهرمانان ارويا، تشديد درامدهاى تلويزيونى

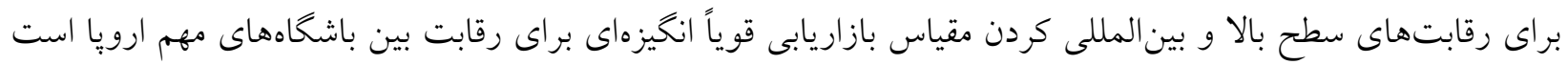

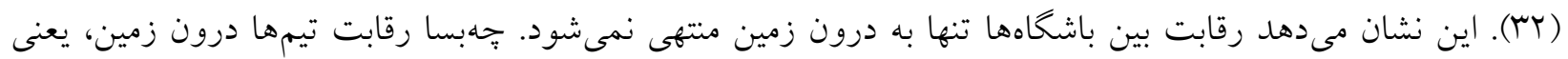
عملكرد تيم بهعنوان يك مؤلفه از خوشنامى تيم؛ ايجادكننده بسترى است براى بيامدهاى مطلوبى كه مىتواند رقابت بيرون زمين را كه عموماً از جنس تجارت است، شكل دهد. درحالى كه در ليخ برتر ايران جيزى بنام رقابت تجارى ديده

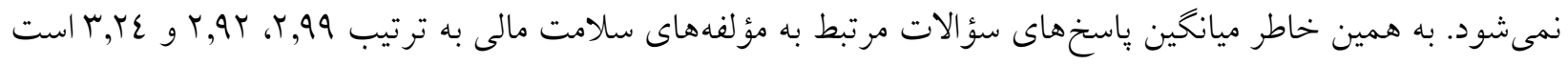
كه با توجه به طيف ينج ارزشى ليكرت نشاندهنده مقدار متوسط به بإيينى است. درحالى كه گويههاى سلامت مالى به

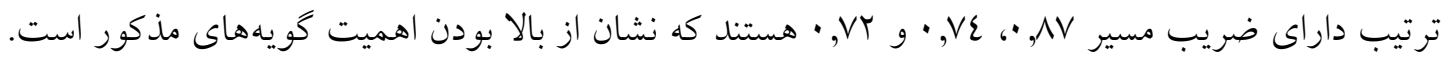
با توجه به ضريب مسير بين مسئوليتهاى اجتماعى و خوشنامى تيم ساع, · و رفتارهاى حمايتى عه, · است كه نشان از

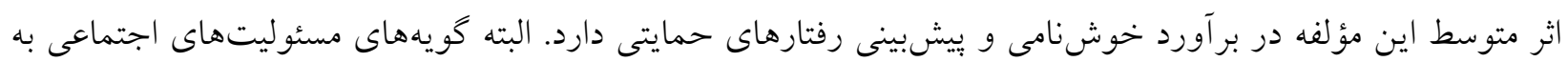
غير از يك گويه داراى ضريب مسير 10, •، 19, · و rV, • است كه نشان از بالا بودن اثر اين كويهها است. درواقع

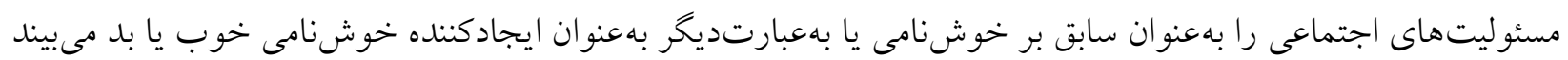
( سٓ). اين در حالى است كه بخشنده و همكاران (•r) در بررسى اثر مسئوليتهاى اجتماعى بر خوشنامى تيم در ليخ

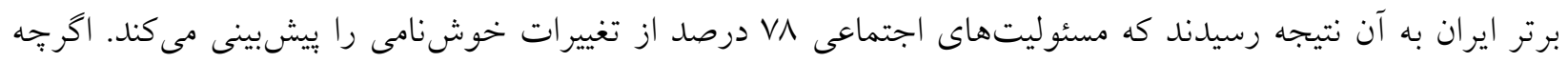

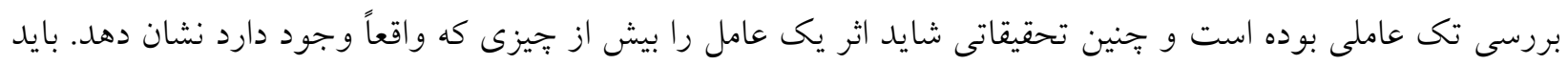

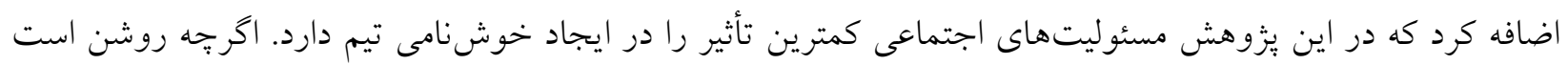

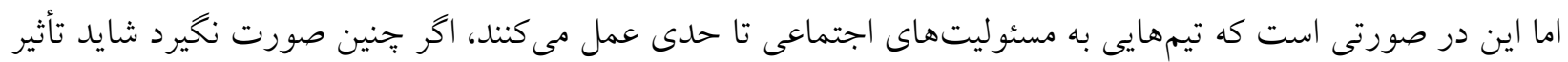
آن بر خوشنامى تيم بسيار بالاتر باشد. درواقع ميزان كنش منفى مسئوليتهاى اجتماعى بيشتر از كنش مثبت آن است. مسئله ادراك خوشنامى كه به سازه هيجانى خوشنامى شهرت دارد، نتايج جالبى را به دست داده است. جدول ع نشان مى دهد كه از بين مؤلفههاى خوشنامى تيم تنها دو مؤلفه (عملكرد تيم و تماشاكر گرايى) اثر معنادارى داشتهاند. عملكرد تيم به دليل اينكه تنها محصول تيمهاى مذكور در ليخ برتر فوتبال ايران است بر ادراك تماشاكران از خوشنامى اثر گذار است. مؤلفه ديخر تماشاگر گرايى است كه ميزان توجهى است كه تيم به تماشاكران دارد. كاملاً منطقى به نظر مى آيد كه

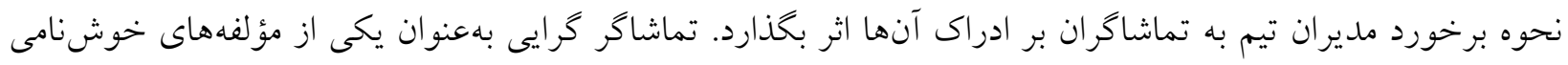

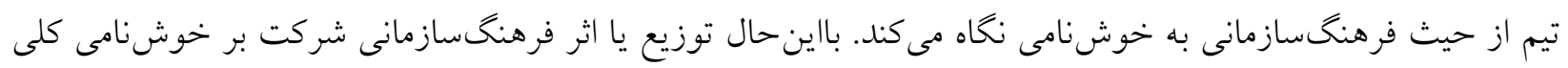

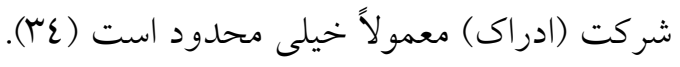




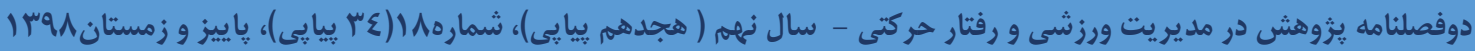

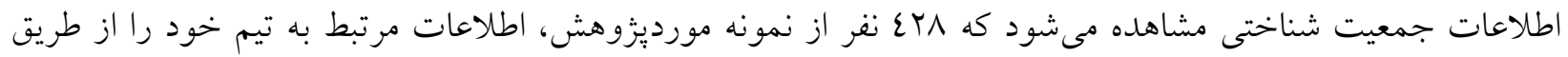
شبكههاى اجتماعى كسب مى كنند. به علت محبوبيت رسانه اجتماعى، برندهاى ورزشى زمان و منابع قابل توجهى را براى راهاندازى مشاركت و ارتباطات آنلاين سرمايه كذارى مى كنند. رويدادهاى مانند سوير بال، جام جهانى فوتبال و المبيك، تيمهاى حرفهاى مانند منجستر يونايتد و رئال مادريد و برندهايى شامل كانورس، ليونل مسى و كريستيانو رونالدو منابع قابل توجهى براى ايجاد كاركردهاى رسانه اجتماعى درون استراتزى بازاريابى خودشان صرف كردند (مَ). مىبايد عنايت داشت كه با توجه به تقاضاى بسيارى زيادى كه تماشاكران براى كسب اطلاعات نسبت به تيمهاى خودشان از طريق فضاى مجازى دارند، روابط عمومى تيمها بايد اين فضا را سازماندهى كنند. جرا در بحث خوشنامى، شركت و سازمانهاى بزرى دنيا در حال حركت به سمت خوشنامى آنلاين خود هستند كه ايجاد نوعى هويت ديجيتال براى آنها است (7س،

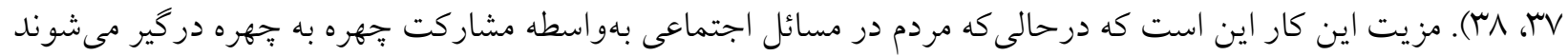
يلتفرمهاى رسانهى اجتماعى مردم را قادر ساخته تا در فعاليت و حمايت بدون داشتن حضور فيزيكى مشاركت كنند (Y).

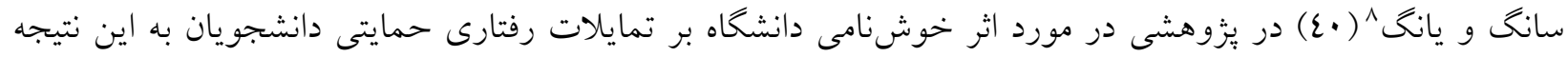

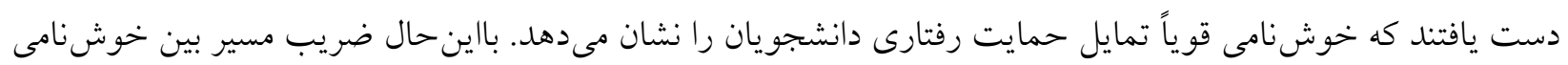

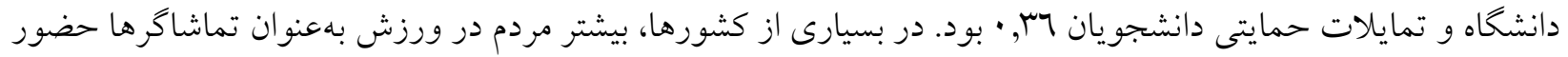
دارند بجاى اينكه مشاركت فعال داشته باشند (1) كه ايران هم ازجمله همين كشورها است درحالىكه باشكاهها استاديومهاى خود را بازسازى مى كنند، نقل و انتقالات بازيكنان ستاره خود را انجام مىدهند، بهترين مربىها را به كار مى كيرند و محصولات تجارى توليد مى كنند تا طرفداران تبديل به مشتريانى شوند كه اين خدمات و محصولات را مصرف كنند ( اع)؛ اما نبود اين سازوكارها در بين تيمهاى ليگ برتر ايران، مشاركت فعال تماشاكران را به تماشاكران غيرفعالى

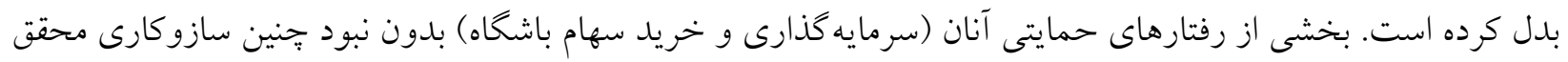

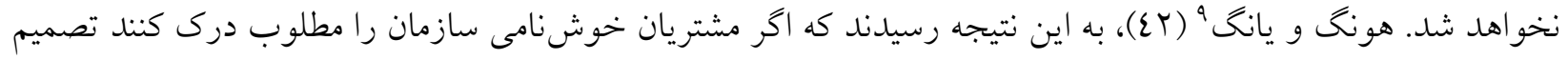

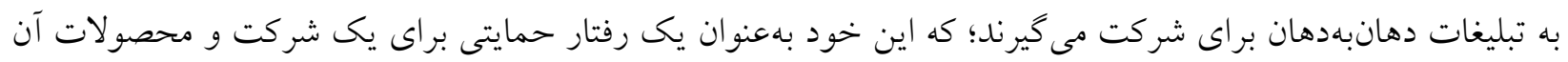
بهحساب مى آيد. شاما و حسن 'ل (rع) در بررسى اثر خوشنامى بر تمايلات رفتارى و بيامدهاى رفتارى مشتريان به اين نتيجه رسيدند كه خوشنامى مى تواند تا VN, • تمايلات رفتارى را بيشبينى كند. اگرجهه اين ارتباط براى مخاطبين عمومى

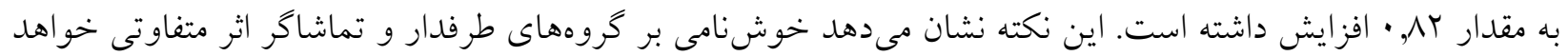

يونزى و همكاران (YN)، با بررسى اثر ادراى خوشنامى بهعنوان يكى مؤلفهى هيجانى از خوشنامى بر رفتارهاى حمايتى در جهار شركت مجزا به اين نتيجه رسيدند كه در بخش خدمات عمومى جامعه ارتباط اين دو بی, •، شركتهاى داروسازى 


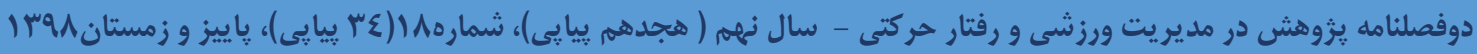

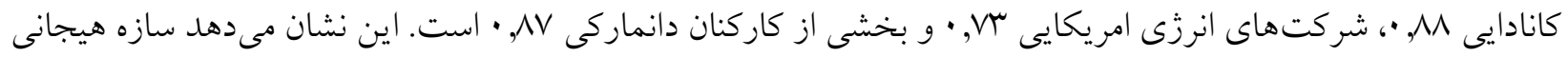
خوشنامى به ميزان زيادى بر رفتارهاى حمايتى اثر كذار است. اين در حالى است كه در اين بزوهش اثر ادراك خوشنامى بر رفتارهاى حمايتى عq, · بوده است. شايد بخشى از آن مربوط به اين باشد كه در ورزش بيش از ديخر صنايع احساسات و عواطف دخالت دارد. اخر جهه سعى شد يرسشنامهها در فضايى عارى از احساسات و هيجانات تكميل شود اما به اشتراك كذاشتن نظرات در صفحههاى توزيع كننده برسشنامه بين هواداران مىتواند عاملى بر اين مسئله باشد.

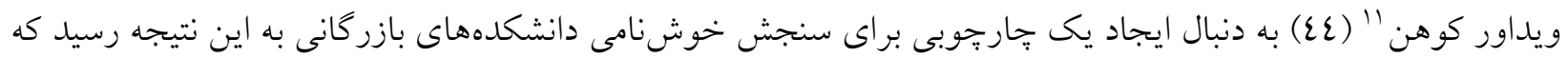
ميزان ارتباط بين خوشنامى و نبض خوشنامى (در اين بزٔوهش ادراك خوشنامى ناميده شده است) M M, · است. اين در

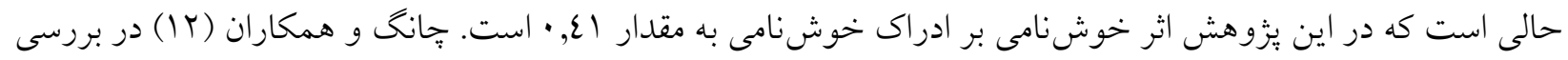
اثر خوشنامى تيم مبتنى بر تماشاگران بر اعتماد و هويت تيم، اثر خوشنامى تيم را بر اعتماد 9, · برآورد كردند. اين در حالى است كه اعتماد در اين بزؤهش بهعنوان يكى از كويههاى ادراك خوشن نامى است كه ضريب مسير آن V7, • است. د.لينيز و رودريكرز " (0ع) در يك مطالعه در بررسى اثر تصوير كاركردى و تصوير هيجانى بر خوشنامى تيم به اين نتيجه رسيدند كه ميزان اثر تصوير كاركردى 009, • و اثر تصوير هيجانى لــب, • است. با توجه به اينكه تصوير بهعنوان بيش سازههاى خوشنامى در نظر گرفته مىشوند، تحقيق د.لينيز و رودريخرز (0) اگرجه در بخش خدمات صورت گرفته

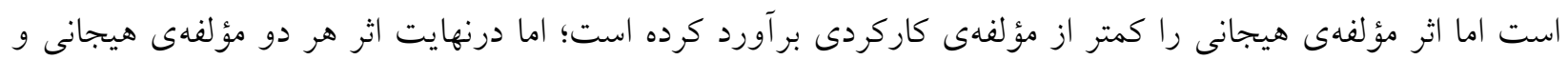
كاركردى بر وفادارى مشتريان شركتهاى موردمطالعه به يك اندازه بود. خجيزى كه خلاف آن در اين يزوهش به جشم مىخورد. نبض خوشنامى (ادراى خوشنامى) بهعنوان يك سازه هيجانى اثر بيشترى نسبت به مؤلفهى كاركردى و شناختى بر رفتارهاى حمايتى دارد.

خوشنامى تيم، بهعنوان سازهاى نويا جهه در عرصه صنايع و جهه در صنعت ورزش نياز به يزوهشهاى بيشترى را طلب مى كند. نتايج تحقيق اگرجهه وجود ارتباط بين متغيرهاى يزوهش را مورد تائيد قرارداد اما شدت اين ارتباط كمى بايين به نظر مىرسد. يكى از يُشنهادهاى اين است كه ارزش سهام تيمها موردسنجش قرار بخيرد كه با توجه به عدم خصوصىسازى باشگاهها در ايران اين امر محقق نمىشود؛ اما سنجش مداوم و ايجاد مديريت خوشنامى تيمها درون كميتههاى بازاريابى باشگاه مىتواند اثربخشى برنامهاى خوشنامى را نشان دهد. از طرف ديخر ذكر اين مسئله الزامى است كه همانكونه كه نويله و همكاران (1) در بررسى خوشنامى سازمانى و ارتباط آن با عملكرد مالى به اين نتيجه رسيدند كه خوشنامى سازمانى مى تو اند بر عملكرد مالى آتى شركت اثر مثبت داشته باشد، اين در حالى است كه سلامت مالى خود يكى از مؤلفههاى تعيين كننده خوشنامى است. اينيك رابطه متعامل بين اين دو ايجاد مى كند كه درنهايت منجر به تزايد مثبت هم خوشنامى و هم عملكرد مالى خواهد شد.

\footnotetext{
11. Vidaver-Cohen

${ }^{12}$. de Leaniz \& Rodríguez
} 


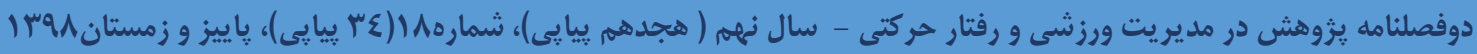

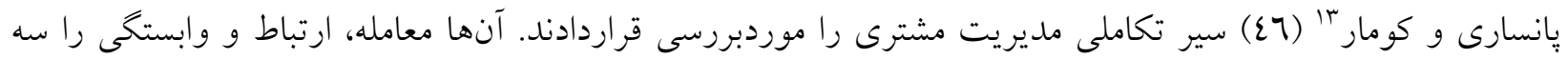
مرحله مديريت مشترى در نظر گرفتند. ايجاد اعتماد و تعهل در مشترى در مرحلهى ارتباط قرار دارد و هيجان در مرحله وابستكى است؛ اما نتايج تحقيق حاضر نشان مىدهد كه در ورزش مديريت ارتباط با مشترى مىتواند وارونه صورت بحيرد. تماشاكران در كام اول با هيجان خود وارد ورزشكاه مىشوند؛ هدايت اين هيجان همانطور كه نتايج آمارى نشان داد تأثير خوبى بر رفتارهاى حمايتى آنان دارد. رفتارهاى حمايتى درواقع مرحله معامله در مدل پانسارى و كومار (27) است. مديران يِيش از يرداختن به معامله با تماشاكران بايد بتوانند اعتماد را در بين طرفداران و تماشاكران خود ايجاد كنند.

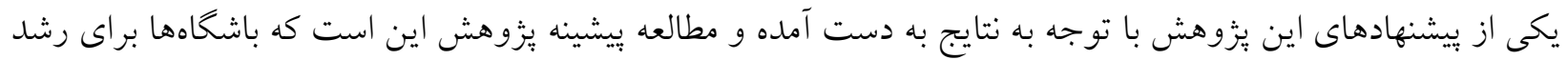

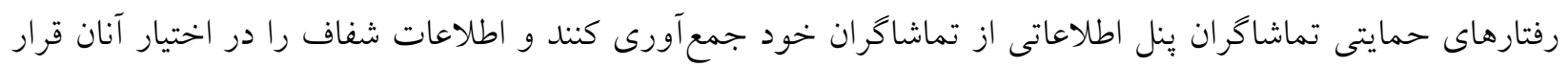
دهند. هور گان و همكارانعًا (ZV) با بررسى مدل اعتماد- خوشنامى ارتباطات باز و صادقانه را منبع اصلى خوشنامى مى داند. اخرجه اين بيشنهاد بركرفته از ديدكاه اطلاعاتى نسبت به خوشنامى است اما عدم وجود اطلاعات و عدم شفافيت اطلاعات در مورد تصميمات باشگاه، مىتواند ضربهى بزرگى در درازمدت به خوش نامى تيمها بزند.

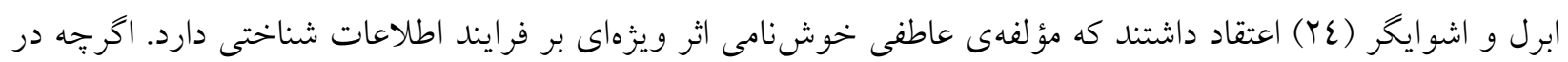
اين يزوهش تنها اثر مؤلفهى شناختى خوشنامى بر مؤلفهى هيجانى موردمطالعه قراركرفته است اما مديران بايد با در نظر

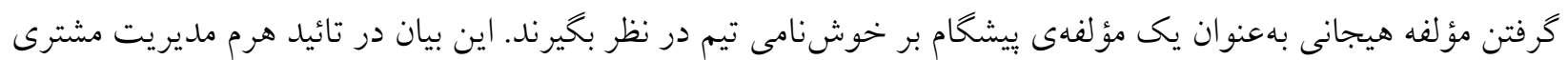
است كه پِانسارى و كومار (27) بيان كردند.

همانطور كه ذكر شد مؤلفهى تاريخجه تيم در سازه خوشنامى تيم اخرجه مبناى نظرى محكمى براى تائيد زيربنايى بودن آن در شناخت خوشنامى تيم دارد، اما توسط محققين به دليل معنادار نبودن آمارى حذف كرديد. البته ميزان ضرايب مسير كويههاى اين مولفه نيز از كمترين مقدار بين كويهها برخوردار بود كه نشان از ضعيف بودن سنجش اين مولفه است. باين حال اين مؤلفه اثر قابلتوجهى بر ادراك خوشنامى داشت. نتايج تحقيقات نشان داده است كه باوجوداينكه تاريخجه تيم بر خوشنامى تيم اثر ندارد اما كار كردن بر روى موارد سازنده تاريخجه تيم مىتواند مؤلفهى هيجانى يا عاطفى خوشنامى را بارزتر نمايد. از طرف ديخر با توجه به تنيدگى خوشنامى و هويت (N) بيشنهاد مىشود بيشتر بر هويت

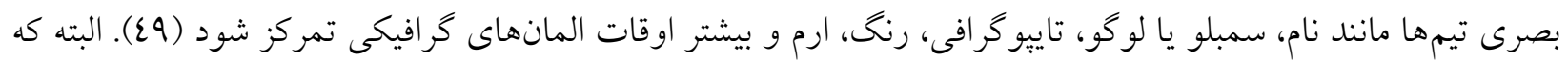
رنگ، نام و لو گو تيمهاى برسبوليس و استقلال مواردى هستند كه تماشاكران براى معرفى تيمهاى خود از آن استفاده مى كنند اما استفاده منفعت آورى هنوز از اين المانها توسط مديريت تيمها نمى شود. يكى از محدوديتهاى اين يزوهش بررسى خوشنامى از يك ديد گاه است و آن ديدگاه مبتنى بر تماشاكران است. يّشنهاد مى شود در تحقيقات بعدى ديد كاه جند گانهاى از سهامداران و ذىنفعان موردبررسى قرار بخيرد تا مشخص شود

\footnotetext{
13. Pansari \& Kumar
}

14. Horgan et al.

https://jrsm.khu.ac.ir/ 


$$
\begin{aligned}
& \text { آيا ارتباطى بين سهامداران و ذىنفعان در برداشت از خوشنامى وجود دارد يا خير. با توجه به ايجاد خوشنامى در طول } \\
& \text { زمان بيشنهاد مىشود مجدد در بزوهش ديخرى به بررسى خوشنامى اين دو تيم برداخته شود تا كاهش يا افزايش آن } \\
& \text { مشاهده شود. } \\
& \text { منابع }
\end{aligned}
$$

1. Neville, B. A. Bell, S. J. \& Mengüç, B. (2005). (Corporate reputation, stakeholders and the social performance-financial performance relationship). European Journal of Marketing, 39(9/10), 1184-1198.

2. 2. Freeman, R. E. (1984). (Strategic management: A stakeholder approach). Cambridge University Press.

3. Walsh, G., \& Beatty, S. E. (2007). (Customer-based corporate reputation of a service firm: scale development and validation). Journal of the Academy of Marketing Science, 35(1), 127-143.

4. Gray, E. R., \& Balmer, J. M. (1998). (Managing corporate image and corporate reputation). Long range planning, 31(5), 695-702.

5. Stacks, D. W., Dodd, M. D., \& Men, L. R. (2013). (Corporate reputation measurement and evaluation). The Handbook of Communication and Corporate Reputation, 559-573.

6. Benoit, W. L. (2013). (Image Repair Theory and corporate reputation). The handbook of communication and corporate reputation, 213-221.

7. Caruana, A., Cohen, C., \& Krentler, K. A. (2006). (Corporate reputation and shareholders' intentions: An attitudinal perspective). Journal of brand management, 13(6), 429-440.

8. Hall, R. (1992). (The strategic analysis of intangible resources). Strategic management journal, 13(2), 135-144.

9. Weigelt, K., \& Camerer, C. (1988). (Reputation and corporate strategy: A review of recent theory and applications). Strategic management journal, 9(5), 443-454.

10. Keh, H. T., \& Xie, Y. (2009). (Corporate reputation and customer behavioral intentions: The roles of trust, identification and commitment). Industrial Marketing Management, 38(7), 732-742.

11. Dierickx, I., \& Cool, K. (1989). (Asset stock accumulation and sustainability of competitive advantage). Management science, 35(12), 1504-1511.

12. Jang, W., Jae Ko, Y., \& Chan-Olmsted, S. M. (2015). (Spectator-based sports team reputation: scale development and validation). International Journal of Sports Marketing and Sponsorship, 16(3), 52-72. 
13. Walsh, G., Beatty, S. E., \& Shiu, E. M. (2009). (The customer-based corporate reputation scale: Replication and short form). Journal of Business Research, 62(10), 924-930.

14. Kesenne, S. (2001). (The different impact of different revenue sharing systems on the competitive balance in professional team sports). European Sport Management Quarterly, 1(3), 210-218.

15. Simcic Bronn, P. (2007). (Relationship outcomes as determinants of reputation). Corporate Communications: An International Journal, 12(4), 376-393.

16. Caruana, A., \& Chircop, S. (2000). (Measuring corporate reputation: A case example). Corporate Reputation Review, 3(1), 43-57.

17. Colleoni, E. (2013). (CSR communication strategies for organizational legitimacy in social media). Corporate Communications: an international journal, 18(2), 228-248.

18. Pérez, A. (2015). (Corporate reputation and CSR reporting to stakeholders: Gaps in the literature and future lines of research). Corporate Communications: An International Journal, 20(1), 11-29.

19. Brammer, S., \& Millington, A. (2005). (Corporate reputation and philanthropy: An empirical analysis). Journal of business ethics, 61(1), 29-44.

20. Walker, M., \& Kent, A. (2009). (Do fans care? Assessing the influence of corporate social responsibility on consumer attitudes in the sport industry). Journal of Sport Management, 23(6), 743-769.

21. Van Leeuwen, L., Quick, S., \& Daniel, K. (2002). (The sport spectator satisfaction model: A conceptual framework for understanding the satisfaction of spectators). Sport Management Review, 5(2), 99-128.

22. Fombrun, C. J., Ponzi, L. J., \& Newburry, W. (2015). (Stakeholder tracking and analysis: The RepTrak® system for measuring corporate reputation). Corporate Reputation Review, 18(1), 3-24.

23. Davis, G. F. (2005). (New directions in corporate governance). Annual review of sociology, 143-162.

24. Eberl, M., \& Schwaiger, M. (2005). (Corporate reputation: disentangling the effects on financial performance). European Journal of Marketing, 39(7/8), 838-854.

25. Siano, A., Kitchen, P. J., \& Giovanna Confetto, M. (2010). (Financial resources and corporate reputation: Toward common management principles for managing corporate reputation). Corporate Communications: An International Journal, 15(1), 68-82.

26. Doorley, J., \& Garcia, H. F. (2011).( Reputation management: The key to successful public relations and corporate communication). Routledge.

27. Newburry, W. (2010). (Reputation and supportive behavior: Moderating impacts of foreignness, industry and local exposure). Corporate Reputation Review, 12(4), 388-405. 
28. Ponzi, L. J., Fombrun, C. J., \& Gardberg, N. A. (2011). (RepTrak ${ }^{\mathrm{TM}}$ pulse: Conceptualizing and validating a short-form measure of corporate reputation). Corporate Reputation Review, 14(1), 15-35.

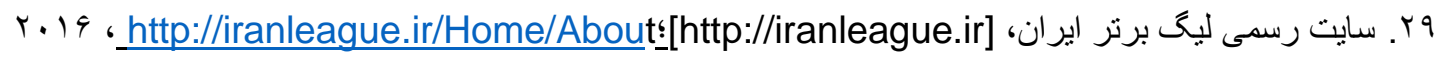

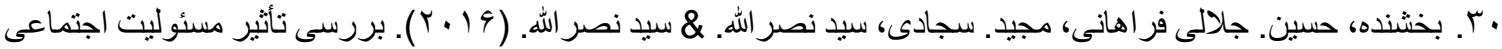

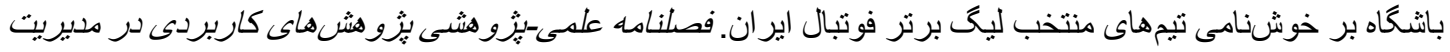

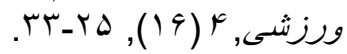

31. Dollinger, M. J., Golden, P. A., \& Saxton, T. (1997). (The effect of reputation on the decision to joint venture). Strategic Management Journal, 127-140.

32. Rohde, M., \& Breuer, C. (2017). (The market for football club investors: a review of theory and empirical evidence from professional European football). European Sport Management Quarterly, 17(3), 265-289.

33. Hillenbrand, C., \& Money, K. (2007). (Corporate responsibility and corporate reputation: Two separate concepts or two sides of the same coin?). Corporate Reputation Review, 10(4), 261-277.

34. Thevissen, F. (2002). (Belgium: corporate reputation in the eye of the Beholder). Corporate Reputation Review, 4(4), 318-326.

35. Filo, K., Lock, D., \& Karg, A. (2015). (Sport and social media research: A review). Sport management review, 18(2), 166-181.

36. Einwiller, S. A., Carroll, C. E., \& Korn, K. (2010). (Under what conditions do the news media influence corporate reputation? The roles of media dependency and need for orientation). Corporate Reputation Review, 12(4), 299-315.

37. Dutot, V., \& Castellano, S. (2015). (Designing a measurement scale for ereputation). Corporate Reputation Review, 18(4), 294-313.

38. Hunter, M. L., \& Soberman, D. A. (2010). ('The Equalizer': Measuring and Explaining the Impact of Online Communities on Consumer Markets). Corporate Reputation Review, 13(4), 225-247.

39. Sanderson, J., \& Gramlich, K. (2016). ("You Go Girl!": Twitter and Conversations about Sport Culture and Gender). Sociology of Sport Journal, 33(2), 113-123.

40. Sung, M., \& Yang, S. U. (2009). (Student-university relationships and reputation: a study of the links between key factors fostering students' supportive behavioral intentions towards their university). Higher Education, 57(6), 787-811.

41. Kaynak, E., Salman, G. G., \& Tatoglu, E. (2008). (An integrative framework linking brand associations and brand loyalty in professional sports). Journal of Brand Management, 15(5), 336-357. 
42. Hong, S. Y., \& Yang, S. U. (2009). (Effects of reputation, relational satisfaction, and customer-company identification on positive word-of-mouth intentions). Journal of Public Relations Research, 21(4), 381-403.

43. Shamma, H. M., \& Hassan, S. S. (2009). (Customer and non-customer perspectives for examining corporate reputation). Journal of Product \& Brand Management, 18(5), 326337.

44. Vidaver-Cohen, D. (2007). (Reputation beyond the rankings: A conceptual framework for business school research). Corporate Reputation Review, 10(4), 278-304.

45. De Leaniz, P. M. G., \& del Bosque Rodríguez, I. R. (2016). (Corporate image and reputation as drivers of customer loyalty). Corporate Reputation Review, 19(2), 166-178.

46. Pansari, A., \& Kumar, V. (2016). (Customer engagement: The construct, antecedents, and consequences). Journal of the Academy of Marketing Science, 1-18.

47. Horgan, I., Ahsan, K., \& Miah, S. (2016). (The importance of attributional trust to corporate). 